\title{
Effect of Price and Brand on Purchase Decision - An Application on Turkish Smart Phone Consumers
}

\author{
Ph.D. Candidate Barış Batuhan Geçit (Beykent University, Turkey) \\ Asst. Prof. Dr. Murad Kayacan (Beykent University, Turkey)
}

\begin{abstract}
Purpose of this study is to discuss whether brand and price has a significant effect on consumers' smart phone purchase decision in Turkey. For this purpose; a survey has been conducted to the Turkish smart phone consumers about the factors affecting their smart phone purchase decision. The results obtained from the survey has been analyzed by using IBM SPSS program. According to the results obtained from the survey the model is accepted as $\mathrm{p}$ value of the model is smaller than 0,05 . According to the analyze both brand and price has a significant effect on Turkish consumers' smart phone purchase decision as both variables' $\mathrm{p}$ values has been found to be smaller than 0,05 . Brand has a positive effect on consumers' smart phone purchase decision whereas price has a negative effect on consumer's smart phone purchase decision.
\end{abstract}

\section{Introduction}

Until the end of the World War II, there was no problem in selling the produced goods, especially because of the lack of serial production and the fact that demand was not more than production (Durmaz, 2006). With the end of the war and the increase in the production capacities of companies, a market structure has emerged in which every manufactured good could be sold.

However, the period called "sales approach" has emerged with the increase of production capacities and increase of demand, as a result, forced sales with psychological pressure has increased. The approach was "Sell whatever you produce, as long as know how to sell it" and the selling strategy was completely misleading, which in fact, did not fully reflect the wishes and needs of consumers (Taşkın, 2009).

In the advanced times, the mass production of businesses meant that unit prices for consumers were getting cheaper. As a result, the pace of demand started to increase and a new approach called "production approach" became valid (Koç, 2016). However, over time, inability to respond to the needs and developments of the market in terms of production (sales) and insufficient supply-demand balance has led to the emergence of "modern marketing approach".

In modern marketing approach, which is accepted today, first step is to determine requirements and desires of consumers then the next is step is production (Taşkın, 2009). As consumer requirements became the focal point; consumer requirements, consumer behavior became an important concept that has to be analyzed by marketers. Many firms have begun to focus on customers for their business activities and as a quality investment tool (Kotler and Armstrong, 2013).

One of the key concepts that creates huge difference in the perception of consumers for the product, which has become one of the focal points of marketing, is brand (Blythe, 2006). Brand is a concept that has an important position in marketing strategies that creates awareness among consumers and differentiate them for companies.

Besides the brand concept, another important concept for marketers is the price. Price is the mechanism for obtaining value for firms (Iacobucci, 2015). For consumers, the price is the amount needed to get a product (Hawkins and Mothersbaugh, 2009).

One of the most important markets where brand perception is most common and the effects on consumers are required to be examined the most is smartphone market.

In the smartphone market, giant companies who constantly rise prices of their products also continue to sell at higher numbers and this fact makes smartphone market an extraordinary market to be analyzed as increasing prices also increases the sell numbers.

The fact that brands' market positions and values are changing and evolving with the developing technologies in the smartphone market is the reason that Apple has been a leader in determining the rules of the market right now, even they were an obscure brand couple of years ago.

Apple went from being an obscure brand to being number one brand of the World (Interbrand, 2017), Samsung utilizing the brand image they had obtained from various product groups for years in the smart phone market and even they suffered Note 7 Explosion Scandal, they can still sell at high rates by courtesy of their high brand image, brands like Huawei and Xiaomi went from being completely unknown brands to preferred brands, Sony went from being one of the biggest technology brands of the world to a poor smart phone brand, Blackberry had a \%20 market in 2009 and currently has a market share of \%0.05 and is in the process of disappearing (Business Insider, 2017).

All these rapid changes in smart phone market shows how dynamic this market is and it is vital to analyze the facts that effect consumer preference in smart phone market. 
Alongside with its dynamic nature, smart phone market it creates very high amount of profit and has a very big transaction mass. Smart phones are one of the most common used products in the World. According to Statista (2017) there are 2.32 Million smart phone users in the World and by the 2020 Statista is also forecasting that there will be 2.87 Million smart phone users in the World.

While smart phone is that common in the whole World, Turkey is one of the top countries in the World in terms of smart phone usage. According to Newzoo (2017) Turkey is the $12^{\text {th }}$ country in terms of smart phone users with 40 Million Smart phone users. According to Poushter (2016) Turkey is once again $12^{\text {th }}$ in terms of smart phone usage percent/total population ratio. So according to these numbers Turkish consumers can be counted as top 15 for the smart phone brands. All these facts make Turkey, which according to The World Bank (2017) is the 17 th biggest economy of the world in terms of GDP, an ideal and an appropriate market to be analyzed in terms of smart phone consumption trends and the main reasons of smart phone preference.

To analyze the facts that effect consumer preference in smart phone market; price and brand has been selected as the most appropriate variables after reviewing the academic literature.

\section{Literature}

In terms of marketing, it is undoubtedly very important to examine the factors that affect the purchase decision of consumers. In the group of products that is analyzed, being able to know which reasons lead consumers to buy certain brands or products; may be important in terms of businesses that want to become big brands. That is because they can determine how to act in the future and what strategies they should implement, and how they can eventually achieve a superior position in the competition. The type of consumer analyzed in this study is not the industrial consumer, but the final consumer. Because the smartphone is a final consumer.

Consumer behavior can be defined as the processes directly related to the acquisition and use of goods and services, which are the economic values of individuals, and the decisions that determine and determine these activities (Tek, 1999).

As mentioned above smart phone is a final consumer product and consumer buying behavior is purchasing behavior for personal or family use (Dibb, Simkin and Pride, 2012, p.148).

Price is the amount of money charged for a product or a service. In other words, price is the sum of all the values that customers give up to gain the benefits of having or using a product or service. Historically, price has been the major factor affecting buyer choice. In recent decades, however, nonprice factors have gained increasing importance. Even so, price remains one of the most important elements that determines a firm's market share and profitability (Kotler and Armstrong, 2013, p.312).

Price is the most visible element of the marketing mix, and pricing policies are being questioned by consumers frequently. If consumers think that prices are unfair, they can leave the firm or spread negative information to other consumers.

Low price can have a positive effect as consumers would demand to pay lower prices but it can also have a negative effect as low price usually decreases the brand image of products and brands. High price can vice versa have a negative effect on consumers as they don't want to pay higher prices but it can increase the brand image.

If product development, promotion and distribution are the seeds of business success, price is the harvest (Kotler and Armstrong, 2013, p.310).

While price is seen as an important factor to affect the dynamics of a market, brand is also regarded as an important variable to affect the dynamics of competition and perception of consumers.

Brand is largely associated with the attributes of the product, benefits, use values, user culture, and personality and user behavior. Every brand has a unique chronology and experience. These are built over time through strong and consistent communication wherever the brand manifests itself from business cards to electronic communication such as television commercials, internet and print media, and finally to billboards (Rajagopal, 2017, p.1).

Brand generates image for product which creates awareness for consumers. Brand helps companies to position themselves in the market. Positioning the product or the brand helps company to decide the desired consumer group, potential market rivals and competition and as a result the long term plans of the company. Brand basically helps firms to differentiate and position themselves within the market competition and for the consumers.

If we give an example for the importance of awareness on consumers; Apple's easy-to-use, aesthetic and technological music player series, launched in 2001, has been successful in a short time. On top of that, the iPod shuffle, IPod nano and IPod touch, which are sold in different prices and quality varieties of IPod, have been introduced into the market. IPod, which sold over 220 million in eight years, was also the pioneer of IPhone 's launch of Apple' s actual explosion (Aaker, 2011, p. 157). Thanks to the brand image and the awareness on consumers obtained by iPod's, iPhone product made an explosive departure in the smart phone market. 
Marketing literature mainly supports the idea that brand and price have a significant effect on consumers' purchase decision but a statistical analysis should be done to prove these ideas and especially for a certain product group like smart phone, which has a very different market dynamic compared to other products, it is very important to do such an analysis.

\section{Model}

Model of this study is as following (Table 1):

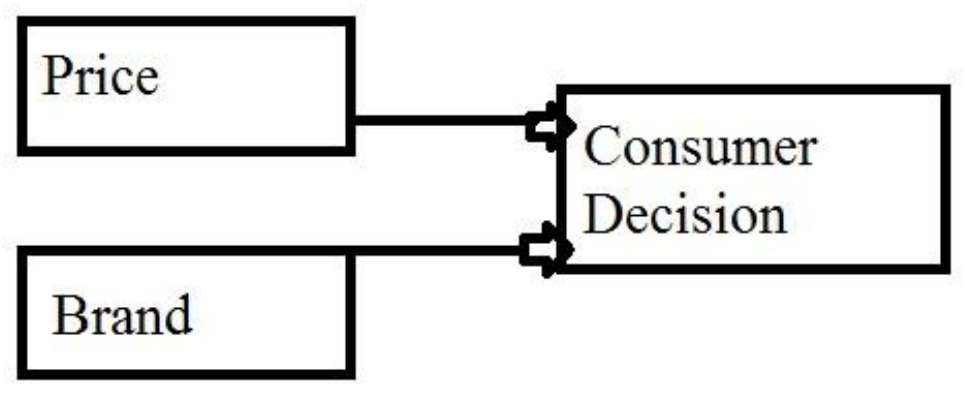

Table 1: Price and Brand's Effect on Consumer Decision

H1: Price has a significant effect on consumers' smart phone purchase decision.

H2: Brand has a significant effect on consumers' smart phone purchase decision.

\section{Methodology}

A survey has been conducted to the 384 Turkish smart phone consumers. The results have been conducted via survey has been analyzed with using IBM SPSS 22 programme and regression analysis has been made for the significance and the positivity of the analysis.

\section{Analysis}

Firstly, normality analysis has been made to find out the generalizability of the dataset. Normality analysis is as following (Table 2):

\begin{tabular}{lll}
\hline $\begin{array}{l}\text { Variable and } \\
\text { Question Number of the Variable }\end{array}$ & Skewness & Kurtosis \\
\hline Purchase Decision & $-1,974$ & 3,679 \\
\hline Brand 1 & $-0,275$ & $-1,006$ \\
\hline Brand 2 & $-0,114$ & $-1,018$ \\
\hline Brand 3 & $-0,531$ & $-0,042$ \\
\hline Price 1 & $-0,275$ & $-1,006$ \\
\hline Price 2 & 1,074 & 0,323 \\
\hline Price 3 & $-0,148$ & $-0,701$ \\
\hline
\end{tabular}

Table 2: Normality Analysis

When the normality distributions of the data are examined; The p values in Kolmogorov-Smirnov and ShapiroWilk must be greater than 0.05 in order to be able to accept the normal distribution of data. The $\mathrm{p}$ values in the analysis results were mainly lower than 0.05 . On the other hand, when we look at the values of Skewness and Kurtosis, another value that is considered valid for normality distribution of the data, it is seen that a large part of the data is within the acceptable values of -3 and +3 . In this direction, the data can be interpreted as normally distributed.

Regression analysis has been made to expresses the significance between the variables and analyze its power.

Regression analysis is as following (Table 3): 


\begin{tabular}{|cl|l|l|l|l|l|}
\hline \multicolumn{2}{|c|}{ Model } & Sum of Squares & $\mathrm{df}$ & Mean Square & $\mathrm{F}$ & Sig. \\
\hline \multirow{3}{*}{1} & Regression & 12,939 & 2 & 6,469 & 16,367 &, $000^{\mathrm{b}}$ \\
\cline { 2 - 8 } & Residual & 150,600 & 381 &, 395 & & \\
\cline { 2 - 7 } & Total & 163,539 & 383 & & & \\
\hline
\end{tabular}

Table 3: Regression Analysis I

According to the regression analysis; the model is valid (accepted) as the Sig. (p) value is lower than 0,05.

\begin{tabular}{|c|c|c|c|c|c|c|}
\hline \multirow[b]{2}{*}{ Model } & & \multicolumn{2}{|c|}{ Unstandardized Coefficients } & $\begin{array}{c}\text { Standardized } \\
\text { Coefficients }\end{array}$ & \multirow[b]{2}{*}{$\mathrm{t}$} & \multirow[b]{2}{*}{ Sig. } \\
\hline & & $\mathrm{B}$ & Std. Error & Beta & & \\
\hline \multirow[t]{3}{*}{1} & (Constant) & 4,119 &, 116 & & 35,405 &, 000 \\
\hline & Brand & ,116 & 043 & ,177 & 2,712 & ,007 \\
\hline & Price &,- 306 & 053 &,- 379 & $-5,796$ &, 000 \\
\hline
\end{tabular}

Table 4: Regression Analysis II

After obtaining the result of the model as valid, the second table shows the significance of the effect of two independent variables to dependent variable.

Again Sig. (p) value should be lower than 0,05 for independent variables to have a significant effect on consumer preference dependent variable.

As seen from the table, both brand and price variables have a significant effect on consumers purchase preference for smart phone.

Beta value shows the positivity and negativity of these relations.

According to the Beta value; brand has a positive significant effect on smart phone purchase decision. Which means the consumers tend to purchase smart phones who has a better brand image. According to International Data Corporation (2017) Samsung has a \%23.3 market share and Apple has a \%14.7 market share. These two brands have a total of $\% 38$ market share in a market that has numbers of companies.

Interbrand (2017) lists Apple as the number one most valuable brand of the World, whereas they list Samsung as the number seven most valuable brand of the World. So as a result proven by these lists, even Apple switched from number one position in most valuable brand list to number two position in market share; two most valuable brands by has the biggest market share by far. These numbers can be seen in table below.

Switch of Apple and Samsung can be explained by two factors. Firstly, Samsung produces various number of different smart phones like, Samsung S8, Samsung Note, Samsung A series, Samsung J series, etc. However, Apple only produces iPhone. One other fact that may have an effect on consumers preferring Samsung more than Apple is, Apple has been selling smart phones at a very higher price compared to Samsung throughout the years.

However, with the Samsung S8 model, Samsung has reached to the price levels of Apple and even higher prices. Samsung S8 is being sold at 4000 Turkish Liras whereas Apple iPhone 7 is being sold at 3300 Turkish liras. But while segmenting a very high price level of a product, as Samsung still produce lower priced and lower segmented products, they also target the lower and middle incomed consumers and as a result they can sell more.

$\begin{array}{lcccc}\text { BRAND } & \text { MARKET SHARE } & \text { BRAND VALUE } & \text { BRAND VALUE } & \text { FORTUNE GLOBAL } \\ \text { Apple } & \text { (IDC, 2017) } & \text { (Interbrand, 2016) } & \text { (Brandz, 2017) } & \text { LIST (2015) } \\ \text { Samsung } & \% 14,7 & 178 \mathrm{M} \$(1 \mathrm{st}) & 234 \mathrm{M} \$(2 \mathrm{nd}) & 15 \text { th } \\ & \% 23,3 & 51 \mathrm{M} \$(7 \mathrm{th}) & 24 \mathrm{M} \$(37 \mathrm{th}) & 13 \text { th }\end{array}$

Table 5: Samsung and Apple Data Comparison

Price has been found to have a significant effect on consumers' smart phone purchase decision but Beta value has been found as negative so which means price has a negative effect on consumers' smart phone purchase decision. That means as prices increase people don't tend to buy these products.

It can be interpreted as no consumer would prefer to buy a product that increases its prices but that kind of analysis cannot be ensured without such an analysis because it both submits a statistical result and even though Apple increases its price range in every single product

As mentioned above, Samsung also target lower and middle incomed consumers, they sell at high numbers compared to Apple with a \%23,3 market share. It can be easily interpreted that these two firms apply different company strategies. Apple tends to only sell at high price tag and retain high brand image whereas Samsung tries to apply a more balanced strategy where they both try to sell at every price segments and at the same time retaining a high brand image. 
To conclude and summarize; brand and price has been found to have a significant effect on consumers' smart phone purchase decision. Brand has a positive effect whereas price has a negative effect. Which means as brand attributes increase purchase decision increases and when price increases purchase decision decreases. Examining the sale numbers, these hypotheses are supported by two giant companies' sales numbers and apart from this statistical study, brand and price seem to have an effect on each other which can be studied in further studies.

\section{References}

- $\quad$ Aaker, 2011. Brand Relevance - Making Competitors Irrelevant. Jossey Bass.

- Blythe, 2006. Marketing. Sage Publications.

- $\quad$ Brown, 2017. Top 100 Global Brands 2017. Brandz.

- Business Insider, 2017. BlackBerry's share of the global smartphone market is now officially $0 \%$.

- Dibb, Simkin, Pride and Ferrell, 2012. Marketing. London: Cengage Learning.

- $\quad$ Fortune, 2015. Global 500.

- Iacobucci, 2015. Marketing Management. Cengage Learning.

- Interbrand, 2017. Best Global Brands Ranking.

- International Data Corporation Research, 2017. Smartphone Vendor Market Share, 2017 Q1

- Hawkins and Mothersbaugh, 2009. Consumer Behavior - Building Marketing Strategy. McGraw Hil.

- Koç, 2016. Tüketici davranışı ve pazarlama stratejileri: global ve yerel yaklaşım. Seçkin, $7^{\text {th }}$ edition.

- Kotler and Armstrong, 2013. Principles of Marketing. Pearson.

- Newzoo, 2017. Top 50 Countries by Smartphone Users and Penetration.

- Poushter, 2016. Smartphone Ownership and Internet Usage Continues to Climb in Emerging Economies.

- Rajagopal, 2017. Brand Management Strategy. Nova Science Publishers.

- Statista, 2017. Number of smartphone users worldwide from 2014 to 2020 (in billions).

- Taşkın, 2009. Pazarlama esasları. Türkmen Kitabevi.

- Tek, 1999. Pazarlama İlkeleri- Global yönetimsel yaklaşım türkiye uygulamaları. Beta Yayınevi. $8^{\text {th }}$ edition.

- World Bank, 2017. World Bank Databank Database. 